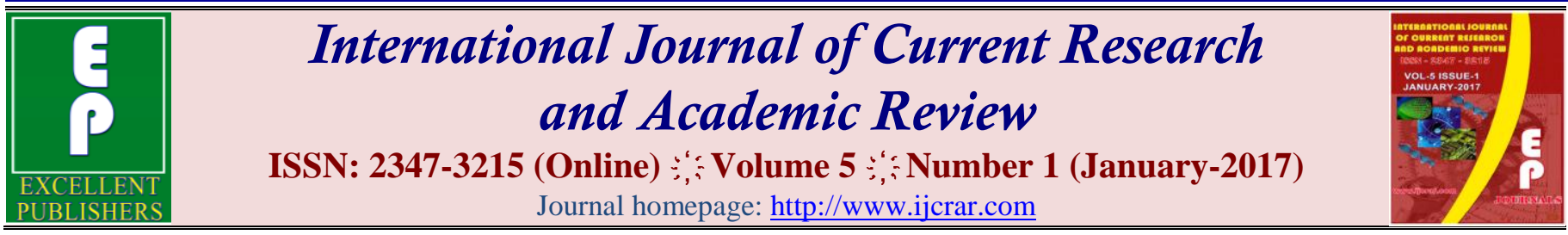

doi: http://dx.doi.org/10.20546/ijcrar.2017.501.004

\title{
Study on Allelopathic Effect of Cocklebur (Xanthium indicum) on Macromolecular Contents of Green Gram (Phaseolus radiatus L.)
}

\author{
S.P. Adhikary* \\ Department of Botany, Aska Science College, Aska-761111, Dist. Ganjam, Odisha \\ *Corresponding author: adhikarysankarprasad@yahoo.co.in
}

\section{Abstract}

Weed releases an array of bioactive secondary metabolites from its various parts such as leaves, stem, root and sometimes decomposed body residues through different mechanism into its surrounding environment. The bioactive chemicals are often termed as allelochemicals and interact with plants which are present in vicinity. Effects of allelochemicals to the agricultural and biological ecosystem are may be positive or negative basing on the type of weed, crop plants and soil medium. Xanthium indicum $L$. and green gram are growing on paddy field after harvesting of the paddy. Green gram is cultivated by farmer on the post harvested paddy field during winter season in the mean time dormant seeds of the test weed are breakdown dormancy by cold treatment and germinated to produce plants along with crop. Hence, a pot experiment was conducted to find out the effect of various types of leachate of Xanthium indicum with its different graded dose $(5,10,15$ and $20 \%)$ on total carbohydrate and protein content. The data of total carbohydrate and protein content obtained revealed a significant negative correlations with increase in the various types of leachate concentrations of test weed and positive correlations with increase in growth period upto 10 DAS thereafter a negative correlation were marked. This indicates that allelopathic stress of various types of leachates of Xanthium indicum L. were phytotoxic to green gram, when incubation period increase (i.e. 10 days after sowing) the degree of toxicity was higher, this might have due to profuse root system and absorbed more allelochemicals by plant as a result altering or blocking the process of intermediate biochemical pathways which reduced the macromolecular contents. The main purpose of this pot culture experiment is to highlight the adverse allelopathic effect of Xanthium indicum $L$. on green gram in agro-ecosystem.
\end{abstract}

\section{Article Info}

Accepted: 28 December 2016

Available Online: 20 January 2017

\section{Keywords}

Macromolecules, Allelopathy, Xanthium indicum, Leachate, Days after Sowing.

\section{Introduction}

Allelopathy is a natural ecological phenomenon in which different organisms affect the functioning of other organisms in their vicinity by releasing secondary metabolites as byproducts called allelochemicals during different physiological processes in plants. Weeds are the most prevalent group of organism interferes with crop plants through competition and allelopathy. The allelochemicals release from weed plants takes place through volatilization, root exudates, leaf leachates and decomposition of plant residues which effect crops and 
succeeding crops in various cropping systems. Liberation of allelochemicals from weeds affects the germination, establishment of growth, yield and physiology of crop plants. They cause substantial reduction in germination and growth of the crop plants by altering various physiological processes such as enzyme activity, protein synthesis and photosynthesis.

The unfavorable effects of allelochemicals on recipient plants are considered as biotic stress called 'allelochemical stress' (Cruz-Ortega et al., 2002). In recent decades, many researchers such as Jabeen et al., (2011), Raoof and Siddiqui, (2012) and Mangal et al., (2013, 2014) have reported the effect of various allelochemicals of different plants on physiological and biochemical processes of the recipient plants. Cutler and Cole (1983) reported that potassium carboxyactractyloside and hypoglyaemic isolated from the residues of cocklebur, strongly inhibited the hypocotyl of wheat and caused a serious decaying and dwarfing in the corn seedling.

Green gram belongs to the family Leguminosae having unusual flower structure, podded fruits, and the ability to form nodules with rhizobia. In the context of human importance, it is with grain legumes contributing $33 \%$ of the dietary protein nitrogen $(\mathrm{N})$ for humans need. Legume seeds contain 20\% - 50\% protein which is highly essential for balanced diet. Green gram is generally catch crop in between cereals to enhance crop yield by increasing soil nitrogen through root nodules of rhizobia.

Cocklebur (Xanthium indicum L) is a weed, which is predominant in post harvested paddy field of study area where farmers of this locality cultivated green gram crop during winter season. Putman and DeFrank (1983), Duzenli et al., (1993) and Kadioglu (1997) reported that cocklebur causes damage on the crops (cotton, onion, sunflower and some vegetables) mostly during summer. Data are needed to know whether cocklebur has any negative allelopathic effect on the crops besides its competition. There are several reports mentioned on allelochemicals from different plants and test plant that negatively affect crops but there is very no information about the effects of Xanthium indicum allelochemicals on the total carbohydrate and protein content. Basing on the above facts and review literatures, the main objective of this study was to evaluate the effect of different concentration of various types of leachate of Xanthium indicum on the total carbohydrate and protein content of green gram (Phaseolus radiatus L.).

\section{Materials and Methods}

In the morning hours Xanthium indicum plants collected at flowering and post flowering stage, from agricultural fields, were washed thoroughly with tap water followed by distilled water to remove the dust and other adhering particles from the surface of plants. Plant parts such as leaves, fruits were separated and allowed to dry-up in an incubator at $40 \pm 2^{0} \mathrm{C}$. Different types of leachate from leaves, fruits and whole plant body were prepared as per the methods described below.

Different plant material i.e. whole plant, leave and fruits were chopped into pieces separately and $200 \mathrm{gm}$ of such chopped materials were allowed to leach for $72 \mathrm{hr}$ in 1 litre of distilled water at $30 \pm 2^{\circ} \mathrm{C}$ as per the method adopted by Padhy et al., (2002). The leachates were filtered through 2 layer gauge cloth and then watman No. 1 filter paper were considered as $20 \%$ concentration and different diluted leachetes $(5,10,15$ and $20 \%)$ with distilled water were prepared and used for seed germination studies.

\section{Seed germination}

The seed germination of green gram influenced by different concentration of leachate were carried out, initially visually selected good seeds of test crop were surface sterilized with $0.03 \%$ formalin solution for 10 minutes separately and then washed thoroughly with distilled water. The surface-sterilized seeds were allowed to germinate in plastic trays $(3 \times 9 \times 12 \mathrm{~cm}$ size $)$ at the rate of 20 seeds per tray containing equal volume of sterilized sand wetted with equal volume of $5,10,15$ and $20 \%$ concentrations of leachate. The seeds were placed $0.5 \mathrm{~cm}$ below from the top sand level. Trays with equal number of seed of test cultivar placed in sand, wetted with distilled water, equal to the volume of different leachate, were served as control set. For accuracy of the experiments, the trays of both treated and control sets were divided into five replicates with 3 trays in each set for each type of leachate. All the trays of both treated and control sets containing seeds were kept in a B.O.D. incubator maintaining $30 \pm 1^{\circ} \mathrm{C}$ for germination. To maintain the wetness of the sand care was taken to add distilled water and leachate as per experimental schedule. Appearance of sprouts from the seeds was considered as the criteria of germination.

All the trays of control and treated sets containing germinated seeds were transferred into the seedling growth chamber maintained at $30 \pm 2^{0} \mathrm{C}$ provided $12 \mathrm{hr}$ 
photoperiod per day with illumination of $2 \pm 0.8$ Klux light intensity from two florescent electric tube lights from top of the seedlings. The seedlings were provided with equal volume of respective test leachates and distilled water as per the experimental design at an interval of 24 hours. The first pair of leaves of seedlings was collected at an interval of 2 days from 6 days after sowing (DAS) till 12 DAS. Changes in macromolecular content (total carbohydrates and protein) in the first pair of leaves during seedling growth were estimated as per the procedures described below.

\section{Extraction and estimation of total carbohydrate}

The first pair leaves of the seedlings collected from both control and treated sets separately at random on 6, 8, 10 and 12 DAS were washed with distilled water, blotted on blotting paper, cut into small pieces and weighed for 250 $\mathrm{mg}$ of such leaf-tissues were ground with $80 \%(\mathrm{v} / \mathrm{v})$ ethanol with pre-chilled mortar and pestle. The homogenate was centrifuged at $5000 \mathrm{Xg}$ for $20 \mathrm{~min}$ at $28 \pm 2^{\circ} \mathrm{C}$ and the supernatant was collected in a test tube and the pellets were again homogenized with little quantity of $80 \%$ ethanol and centrifuged. All the supernatants were pooled together and were evaporated in a water bath till the volume was reduced to slurry of 1 or $2 \mathrm{ml}$. To this slurry distilled water was added to make a definite volume which served as extract of total carbohydrate and content was estimated spectrophotometrically by anthrone method as described by Plumber (1979). To $1 \mathrm{ml}$ of extract and $4 \mathrm{ml}$ of anthrone reagent $\left(2 \mathrm{~g} / \mathrm{l}\right.$ conc. $\left.\mathrm{H}_{2} \mathrm{SO}_{4}\right)$ was added and mixed thoroughly by shaking. The test tubes were placed in a boiling water bath for 10 minutes with marble ball on top to prevent loss of water by evaporation. The reaction mixtures were then cooled and their optical densities were recorded at $620 \mathrm{~nm}$ with help of spectrophotometer. D-Glucose was used for standard curve. For blank, $1 \mathrm{ml}$ of distilled water was used in place of extract. The total carbohydrate content was expressed in $\mathrm{mg} / \mathrm{g}$ fr. wt. of leaf tissues.

\section{Extraction and estimation of protein}

The first pair leaves of the seedlings collected from both control and treated sets separately at random on 6, 8, 10 and 12 DAS were washed with distilled water, blotted on blotting paper, cut into small pieces and weighed for 250 $\mathrm{mg}$ of such leaf-tissues were ground with $80 \%(\mathrm{v} / \mathrm{v})$ ethanol with pre-chilled mortar and pestle. The homogenate was centrifuged at $5000 \mathrm{Xg}$ for $20 \mathrm{~min}$ at $28 \pm 2^{\circ} \mathrm{C}$ and the supernatant was discarded and the pellets were again homogenized with little quantity of 80 $\%$ ethanol and centrifuged. The colorless pellets left over after ethanolic extraction from leaf materials were suspended in ethanol and ether mixture (2:1 and then 1:1) for 30 minutes, centrifuged at $5000 \mathrm{X} \mathrm{g}$ for $20 \mathrm{~min}$. at $4 \pm 1^{\circ} \mathrm{C}$. Then the pellets were suspended in $5 \%$ Trichloro-acetic acid (TCA) (w/v) at $\mathrm{O}^{0} \mathrm{C}$ for 15 minutes, centrifuged at $5000 \mathrm{Xg}$ for $20 \mathrm{~min}$ at $4 \pm 1^{\circ} \mathrm{C}$. The procedure repeated twice and supernatants were discarded. The pellets were treated with $10 \%$ Trichloroacetic acid (TCA) (w/v) at $90 \pm 1^{\circ} \mathrm{C}$ for 15 minutes, cooled and centrifuged at $5000 \mathrm{X} \mathrm{g}$ for $20 \mathrm{~min}$. at $28 \pm 1^{\circ}$ C. Then the pellets, free from lipids and histones, were treated with $5 \mathrm{ml}$ of $1 \mathrm{~N} \mathrm{NaOH}$, heated in a water bath for 20 minutes, cooled and centrifuged at $3000 \mathrm{X}$ g for $20 \mathrm{~min}$. at $28 \pm 2^{\circ} \mathrm{C}$. The supernatants were considered as protein extract and their contents were determined following the method of Lowery et al., (1951). To $0.5 \mathrm{ml}$ of $\mathrm{NaOH}$ extract, $2.5 \mathrm{ml}$ of alkaline reagent (mixture of $50 \mathrm{ml}$ of $2 \% \mathrm{Na}_{2} \mathrm{CO}_{3}$ in $0.1 \mathrm{~N} \mathrm{NaOH}$ and $1 \mathrm{ml}$ of a mixture containing equal amount of $1 \%$ copper sulphate and $2 \%$ sodium potassium tartarate) and $0.5 \mathrm{ml}$ of folinCiocalteau reagent were added. The reaction mixtures were allowed to stand at room temperature $\left(30 \pm 1{ }^{\circ} \mathrm{C}\right)$ for half an hour and the optical densities (O. D.) of the reaction mixtures were measured at $570 \mathrm{~nm}$. Bovine Serum Albumin (BSA) was used as the reference standard. Equal amount of $1 \mathrm{~N} \mathrm{NaOH}$ in place of protein extract and folin reagent were run parallel as blank. The protein content was expressed in $\mathrm{mg} / \mathrm{g}$. fr. wt. of leaf tissues.

\section{Results and Discussions}

Seedling establishment and their growth play a vital role on the productivity of a particular crop. Changes in macromolecular content (total carbohydrates and protein) in the first pair of leaves during seedling growth influenced by different concentrations of various types of lechates of Xanthium indicum plant on green gram are described below.

\section{Total carbohydrate content}

Changes in total carbohydrate content in the first leaf (leaves) of any crop seedling during their growth period are considered as an important parameter as it bears direct relationship with photosynthesis. The results on the influence of various types of different concentrations of aqueous whole-plant, leaves and fruits leachate of Xanthium indicum on total carbohydrate content in leaves of green gram seedling are described below. 
It was observed that the total carbohydrate contents in the first pair of leaves of green gram seedling increased gradually from 4 Das upto10 DAS and then decreased in both control and treated sets. The maximum total carbohydrate content estimated from first pair of leaves of control set seedling on 10 DAS was $0.43 \pm 0.01 \mathrm{mg} / \mathrm{g}$ fr. wt. whereas it was minimum $(0.28 \pm 0.02 \mathrm{mg} / \mathrm{g}$ fr. wt.) on 10 DAS in the leaves of seedling affected by 15 $\%$ leachate. Other concentrations of the leachate exhibited intermediate values during course of seedling growth (Table-1). The total carbohydrate contents in the first pair of leaves exhibited positive correlations with increase in growth period upto 10 DAS and negative correlations with increase in concentrations of leachate throughout the period of observation.

The maximum total carbohydrate content estimated from first pair of leaves of green gram seedlings of control set on 10 DAS was $0.43 \pm 0.01 \mathrm{mg} / \mathrm{g}$ fr. wt. which on 12 DAS decreased to $0.37 \pm 0.01 \mathrm{mg} / \mathrm{g}$ fr. wt. whereas it was minimum $(0.30 \pm 0.02 \mathrm{mg} / \mathrm{g}$ fr. wt. $)$ on $10 \mathrm{DAS}$ in the leaves of seedling affected by $15 \%$ leachate. Other concentrations of the leachate exhibited intermediate values during course of seedling growth (Table-1). The total carbohydrate contents in leaves exhibited positive correlations with advancement of seedling age upto 10 DAS only and negative correlations with increase in concentrations of leachate as was noticed in the case of whole-plant-leachate.

Maximum amount of total carbohydrate content estimated from first pair of leaves of control set seedling on 10 DAS was $0.43 \pm 0.01 \mathrm{mg} / \mathrm{g}$ fr. wt. which later reduced to $0.37 \pm 0.01 \mathrm{mg} / \mathrm{g}$ fr. wt. on $12 \mathrm{DAS}$, whereas it minimum amount of $0.34 \pm 0.02 \mathrm{mg} / \mathrm{g}$ fr. wt. of carbohydrate was estimated from first pair of leaves of test seedling influenced affected by $15 \%$ leachate on 10 DAS. Other concentrations of the leachate exhibited intermediate values during course of seedling growth (Table-1). Like other leachate, it also exhibited positive correlations with increase in growth period upto 10 DAS and negative correlations with increase in concentrations of leachate throughout the period of observation.

During the process of photosynthesis in green tissues, the primary photosynthate is glucose which later-on converts into different forms and enters into various metabolic pathways. The reduction of chlorophyll synthesis in the leaves influenced by all concentrations of various types of leachate directly affected on carbohydrate content in the leaves of the test crop seedlings. Since most of the important enzymes associated with various metabolic pathways are directly or indirectly affected by allelochemicals present in the leachate, the metabolic processes might have disturbed at cellular and subcellular levels resulting lower rate of photosynthesis which have reflected of carbohydrate content in leaves. As chlorophylls have direct bearing on carbohydrate synthesis and accumulation of carbohydrate on plants, it is directly proportional to the amount of chlorophyll present in the leaves. As the allelochemicals present in the leachate caused inhibitory effect on chlorophyll synthesis and content, it is obvious that there should be a lower that of accumulation of carbohydrate in the leaves. This postulation holds true in the present investigation. Similar findings on reduction of carbohydrate content have been reported in the ragi seedling influenced by Eucalyptus globulus leaf-litter-leachate by Pattnaik, (1998) and Padhy et al., (2000). Tripathy, (2000) also reported a decreased amount of carbohydrate content in rice seedlings of two improved cultivars (IR-36 and Swarna) influenced by phyllode-leachate of Acacia auriculaeformis and bark leachate of both Acacia nilotica and Acacia auriculaeformis. Similar findings of Hunsal et al., (1998) in soybean also corroborate the present observation. Saleh (2013) demonstrated that corn seeds with olive processing wastes extract at concentration $3.0 \%(\mathrm{w} / \mathrm{v})$ significantly increased the soluble sugars content in seedlings tissues, while the higher concentrations were inhibitory. The soluble sugars can keep the intracellular osmosis pressure and play important roles in maintaining the normal physiological function of cells (Kohyama \& Nishinari, 1991).

\section{Protein content}

Growth of any plant generally depends on the synthesis of various metabolites, particularly protein, which later on take part on different metabolic activities. Change in protein content in first pair of green gram seedlings influenced by different concentrations of various aqueous-leachate of Xanthium indicum plants are described below.

From the Table- 2 it can be observed that protein content in first pair of leaves of green gram seedling exhibited distinct declined trend by the influence of all concentrations of leachate compared to seedling of control set. The maximum amount of $30.14 \pm 0.01 \mathrm{mg} / \mathrm{g}$ fr. wt. protein content was estimated from green leaves of green gram seedling of control set on 10 DAS whereas during same period of growth, it was only $14.24 \pm 0.02$ $\mathrm{mg} / \mathrm{g}$ fr. wt. in first pair of leaves in the seedling raised in $15 \%$ concentrations of test leachate. 
Other concentrations showed intermediate values (Table2 ). The protein content in leaves exhibited negative correlations with increase in the leachate concentrations and positive correlations with increase in growth period upto 10 DAS only.

In this cultivar, changes in protein contents in first leaves of the seedling also showed more or less similar trends with increase in concentration of leaf-leachate and seedling growth period as were noticed in seedlings influenced by whole-plant-leachate.

In case of fruits-leachate, it can be noted that the minimum protein content estimated from leaves of green gram seedlings grown in $15 \%$ of leachate on 10 DAS was $15.24 \pm 0.02 \mathrm{mg} / \mathrm{g}$ fr. wt., whereas in control set it was $25.30 \pm 0.02 \mathrm{mg} / \mathrm{g}$ fr. wt. All other concentrations of the leachate exhibited intermediate values on different DAS in other seedlings (Table-2). The protein content in leaves of green gram seedlings exhibited negative correlations with increase in the leachate concentrations and positive correlations with increase in growth period upto 10 DAS only.

From the experimental results, it can be observed that the protein content in first pair of leaves in test crop seedlings exhibited declined trends by the influence of all concentrations of whole-plant, leaves and fruits leachate of the test weed plant. This might be due to the interference of phytotoxic and other phenolic compounds present in the different plant parts. The trend indicating decrease of protein level in leaves was comparatively more in seedlings of treated sets than in control seedlings. The effect of phenolic compounds on protein synthesis have been extensively investigated in algae (Van Sumere and Dadonder, 1971, Van Sumere et al., 1972, isolated leaf cell of Velvet leaf (Mersi and Singh, 1993).

Table 1. Effect of different concentrations of various types of aqueous leachate of Xanthium indicum on total carbohydrate content in the first pair of leave of green gram seedlings at different developmental stages.

(Each value is mean of 5 replicates \pm S.E.M. expressed in $\mathrm{mg} / \mathrm{g}$ fresh wt.)

\begin{tabular}{|l|l|c|c|c|c|}
\hline \multicolumn{1}{|c}{$\begin{array}{c}\text { Types of } \\
\text { leachates }\end{array}$} & $\begin{array}{c}\text { Leachate } \\
\text { concentration } \\
(\%)\end{array}$ & 6 DAS & 8 DAS & 10 DAS & 12 DAS \\
\hline Whole-plant & Control & $0.34 \pm 0.06$ & $0.40 \pm 0.03$ & $0.43 \pm 0.02$ & $0.37 \pm 0.01$ \\
\cline { 2 - 6 } & 5 & $0.31 \pm 0.06$ & $0.35 \pm 0.06$ & $0.40 \pm 0.05$ & $0.32 \pm 0.02$ \\
\cline { 2 - 6 } & 10 & $0.27 \pm 0.03$ & $0.32 \pm 0.02$ & $0.35 \pm 0.03$ & $0.20 \pm 0.04$ \\
\cline { 2 - 6 } & 15 & $0.18 \pm 0.08$ & $0.22 \pm 0.02$ & $0.28 \pm 0.02$ & $0.12 \pm 0.02$ \\
\hline \multirow{3}{*}{ Leaves } & Control & $0.34 \pm 0.06$ & $0.40 \pm 0.03$ & $0.43 \pm 0.02$ & $0.37 \pm 0.01$ \\
\cline { 2 - 6 } & 5 & $0.32 \pm 0.08$ & $0.37 \pm 0.02$ & $0.40 \pm 0.04$ & $0.35 \pm 0.01$ \\
\cline { 2 - 6 } & 10 & $0.28 \pm 0.03$ & $0.35 \pm 0.02$ & $0.38 \pm 0.03$ & $0.26 \pm 0.04$ \\
\cline { 2 - 6 } & 15 & $0.17 \pm 0.05$ & $0.25 \pm 0.06$ & $0.30 \pm 0.02$ & $0.15 \pm 0.01$ \\
\hline \multirow{3}{*}{ Fruits } & Control & $0.34 \pm 0.06$ & $0.40 \pm 0.03$ & $0.43 \pm 0.02$ & $0.37 \pm 0.01$ \\
\cline { 2 - 6 } & 5 & $0.33 \pm 0.08$ & $0.38 \pm 0.06$ & $0.41 \pm 0.05$ & $0.36 \pm 0.02$ \\
\cline { 2 - 6 } & 10 & $0.30 \pm 0.03$ & $0.36 \pm 0.02$ & $0.40 \pm 0.03$ & $0.33 \pm 0.04$ \\
\cline { 2 - 6 } & 15 & $0.20 \pm 0.07$ & $0.29 \pm 0.06$ & $0.34 \pm 0.02$ & $0.24 \pm 0.02$ \\
\cline { 2 - 6 } & & & & & \\
\hline
\end{tabular}


Table 2. Effect of different concentrations of various types of aqueous leachate of Xanthium indicum on protein content in the first pair of leave of green gram seedlings at different developmental stages.

(Each value is mean of 5 replicates \pm S.E.M. expressed in $\mathrm{mg} / \mathrm{g}$ fresh wt.)

\begin{tabular}{|c|c|c|c|c|c|}
\hline $\begin{array}{l}\text { Types of } \\
\text { leachates }\end{array}$ & $\begin{array}{c}\text { Leachate } \\
\text { concentration } \\
(\%)\end{array}$ & 6 DAS & 8 DAS & 10 DAS & 12 DAS \\
\hline \multirow[t]{4}{*}{ Whole-plant } & Control & $14.60 \pm 0.06$ & $22.38 \pm 0.03$ & $30.14 \pm 0.02$ & $20.75 \pm 0.04$ \\
\hline & 5 & $09.34 \pm 0.02$ & $17.90 \pm 0.02$ & $24.50 \pm 0.05$ & $14.57 \pm 0.04$ \\
\hline & 10 & $08.26 \pm 0.03$ & $14.43 \pm 0.01$ & $18.29 \pm 0.02$ & $12.27 \pm 0.04$ \\
\hline & 15 & $05.31 \pm 0.04$ & $11.39 \pm 0.02$ & $14.24 \pm 0.02$ & $09.52 \pm 0.05$ \\
\hline \multirow[t]{4}{*}{ Leaves } & Control & $14.60 \pm 0.06$ & $22.38 \pm 0.03$ & $30.14 \pm 0.02$ & $20.75 \pm 0.04$ \\
\hline & 5 & $10.74 \pm 0.04$ & $18.30 \pm 0.03$ & $24.90 \pm 0.02$ & $14.97 \pm 0.04$ \\
\hline & 10 & $08.66 \pm 0.03$ & $14.83 \pm 0.02$ & $18.69 \pm 0.02$ & $12.67 \pm 0.04$ \\
\hline & 15 & $05.71 \pm 0.04$ & $11.79 \pm 0.02$ & $14.64 \pm 0.02$ & $09.92 \pm 0.05$ \\
\hline \multirow[t]{4}{*}{ Fruits } & Control & $14.60 \pm 0.06$ & $22.38 \pm 0.03$ & $30.14 \pm 0.02$ & $20.75 \pm 0.04$ \\
\hline & 5 & $11.31 \pm 0.03$ & $18.90 \pm 0.04$ & $25.30 \pm 0.02$ & $15.57 \pm 0.01$ \\
\hline & 10 & $09.26 \pm 0.02$ & $15.43 \pm 0.03$ & $19.29 \pm 0.02$ & $13.27 \pm 0.04$ \\
\hline & 15 & $06.31 \pm 0.03$ & $12.39 \pm 0.02$ & $15.24 \pm 0.01$ & $09.52 \pm 0.05$ \\
\hline
\end{tabular}

Comerson and Julin (1980) have reported the inhibition of protein synthesis in lettuce leaves affected by allelopathic compounds. Similarly, Pattnaik (1998) and Padhy et al., (2000), have reported the adverse effect of allelochemicals of Eucalyptus globulus on protein content in leaves of several crop plants. Baziramakenga et al., (1997) reported that phenolic acids, the major allelochemicals of various plant leachates and extracts, interfere with protein metabolism. Hence, the decrease of protein content influenced by different concentrations of leachates might be due to impact of those allelochemicals present in the leachates of different plant parts of test weed. The decline in protein content on the advancement of seedling age indicate that the leaves might have attained the age of senescence, where the amino nitrogen content increases with decline in protein content. The reports of Kumar (1983) agree to this observation. Thiaman et al., (1974) reported that in the attached senescing leaves of oat, the protein content gradually declined and ultimately reached to zero level. The soluble proteins with colloidal properties are main components in cell matrix, and they can increase protoplasm hydration (Fisher et al., 1992). Allelopathic stress of test weed on crop might have caused degradation of soluble protein and disorganize the cellular matrix as a result cell undergoes to atrophy. Hence, it is confirmed that the phytotoxic compounds present in the various types of leachates of the test weed which accelerate the reduction of protein content in seedlings of test cultivars.

\section{Acknowledgement}

The authors wish to express sincere thanks to the Principal, Aska Science College, Aska for his encouragement and providing necessary facilities. The authors are also grateful to Prof. Bhaskar Padhy, (Retd.), Department of Botany, Berhampur University, Berhampur, Odisha for his constant support, encouragement and revision. 


\section{References}

Baziramakenga, R., Leroux, G.D., Simard, R.R. and Nadeau, P. 1997. Allelopathic effects of phenolic acids on nucleic acids and protein levels in soyabean seedlings. Can. J. Bot., 75: 445-450.

Cameron, H.T. and Julian, G.R. 1980. Inhibition of protein synthesis in lettuce (Lactuca sativa L.) by allelopathic compounds. J. Chem. Ecol., 6: 989995.

Cruz-Ortega, R., Ayala-Cordero, G. and Anaya, A.L., 2002. Allelochemical stress produced by the aqueous leachate of Callicarpa acuminate, effects roots of bean, maize and tomato. Physiol. Plant, 116: 20-27.

Cutler, H.G. and Cole, R.J. 1983. Carboxyactractyloside compound from Xanthium stumarium and Atractylus gummifera with plant growth inhibiting properties. J. Natural products, 46: 609-613

Dunenli, A., Uygur, F.N., Turkmen, N., Uygur, S. and Boz, O. 1993. The features of the important weed species in the Mediterrenean Region Turkey. Turkish I. Herbology Congr., 3-5 Feb.1993,Adanaturkey:77-86.

Fisher, D.B., Wu, Y. and Ku, M.S.B. 1992. Turnover of soluble proteins in the wheat sieve tube. Plant Physiol., 100(3): 1433-1441.

Hunsal, C.S., Channal, H.T., Algawardi, A.R. and Patil, R.H. 1998. Scope of allelopathy research in agroforestry system in South India. In: Abstract-III, International Congress L Agriculture and Forestry, (Eds. S.S. Norwal; C.J. Itnal; R.E. Hogland, R.H. Dilday; and M.J. Reigosa), Indian Society of Allelopathy, Pp. 70.

Jabeen, N., Ahmed, M., Shaukat, S.S. 2011. Interactive activity of Asphodelus tenuifolius on germination and growth of wheat (Triticum aestivium L.) and sorghum (Sorghum bicolor L.). Pak. J. Bot., 43 (1): 325-331.

Kadioglu, I. 1997. Studies on germination biology and germination depth of some of the weed species found in cotton fields in Mediterrenean Region Turkey. Turkish II. Herbology Congr., 1-4 Sept.1997, Izmir-turkey: 205-218.

Kohyama, K. and Nishinari, K. 1991. Effect of soluble sugars on gelatinization and retrogradation of sweet potato starch. J. Agricultural and Food Chem., 39 (8): 1406-1410.

Kumar, K.B. 1983. Studies on physiological of senescence in crop plant: II. Effect of growth regulation and photoperiod on leaf senescence in Eleusine coracana Gaertn. Cv. PR.202. Ph.D.
Thesis, Berhampur University, Berhampur, Odisha,India.

Lowery, O.H., Rosebrough, N.J., Farr, A.L. and Randal, R.J. 1951. Protein measurement with Folinphenol reagent. J. Biol. Chem., 193: 265-275.

Mangal, K.M., Bhat, J.L., Kumar, A., Saini, P. 2013. Allelopathic effect of aqueous leaves extract of Moringa oleifera L. on seedling growth of Cicer arietinum L. African J. Agri., 8(12): 1028-1032.

Mangal, K.M., Bhat, J.L., Kumar, A., Saini, P. 2014. Germination and seedling Vigour of Vigna sinensis as affected by allelopathy of Calotropis gigantea L. Indian J. Agricultural Res., 48 (1):29-34.

Mersie, W. and Singh, M. 1993. Phenolic acids affect photosynthesis and protein synthesis by isolated leaf cells of velvet leaf. J. Chem. Ecol., 19: 1293-1301.

Padhy, B., Mishra, P. and Gantayat, P.K., 2002. The Allium test, An alternative bioassay in allelopathic studies: Impact of aqueous phyllode-litter leachate of Acacia auriculaeformis. Indian J. Environm. Eco-Planning, 6: 99-104.

Padhy, B., Patnaik P.K. and Tripathy, A.K., 2000. Allelopathic potential of Eucalyptus leaf litterleachate on the germination and seedling growth of finger-millet. Allelopathy J., 7(1): Pp. 69-78.

Patnaik, P.K. 1998. Studies on Allelopathic effects of Eucalyptus leaves on ragi (Finger millet) crop, $\mathrm{Ph}$. D. Thesis, Berhampur University, Berhampur, Odisha.

Plummer, T.D. 1979. Estimation of carbohydrate by the anthrone method In: an Introduction to Practical biochemistry, second edition, (Ed. T.D. Plummer), Tata Mc Graw Hill Publishing Company Ltd., Pp. 183-184.

Putman, A.R. and DeFrank, J. 1983. Use of phytotoxic plant residues for selective weed control. Crop Prot., 2: 173-181.

Raoof, K.M.A., Siddiqui, M.B. 2012. Allelopathic effect of aqueous extracts of different parts of Tinospora cordifolia (Willd.) Micrs on some weed plants. $J$. Agric. Ext. Rural Dev., 4(6):115-119.

Saleh, A.M. 2013. In vitro assessment of allelopathic potential of olive processing waste on maize (Zea mays L.). Egypt. J. Exp. Biol., 9: 35-39.

Thiamann, K.V., Tetley, R.M. and Thanh, T.V. 1974. Metabolism of oat leaves during senssence, II. Senesence in leaves attached to the plant. Plant Physiol., 54: 854-862.

Tripathy, A.K. 2000. Studies on the allelopathic effect of Acacia species on some rice ( Oryza Saliva L.) 
cultivoers. Ph.D. Thesis, Berhampur University, Berhampur, Orissa, India.

Van Sumere, C.F. and Dedonder, A., 1971. The effect of some naturally occurring and synthetic phenolics and related compounds on the uptake and incorporation of phenyl-alanine $1-14 \mathrm{C}$ by Chlorella vulgaris. Z. Pflanzenphysiol., 65: 176-182.
Van Sumere, C.F., Cottenie, J., De Gree, J. and Kint, J., 1972. Biochemical studies in relation to the possible germination regulatory role of naturally occurring coumarin and phenolics. Recent $A d v$. Phytochem., 4: 165-221.

\section{How to cite this article:}

Adhikary, S.P. 2017. Study on Allelopathic Effect of Cocklebur (Xanthium indicum) on Macromolecular Contents of Green Gram (Phaseolus radiatus L.). Int.J.Curr.Res.Aca.Rev. 5(1), 34-41.

doi: http://dx.doi.org/10.20546/ijcrar.2017.501.004 